\title{
Review \\ Fibrin Clot Properties in Atherosclerotic Vascular Disease: From Pathophysiology to Clinical Outcomes
}

\author{
Michał Ząbczyk ${ }^{1,2,+}$ (D) Joanna Natorska ${ }^{1,2,+}$ and Anetta Undas ${ }^{1,2, *}$ \\ 1 John Paul II Hospital, 31-202 Kraków, Poland; michalzabczyk@op.pl (M.Z.); \\ j.natorska@szpitaljp2.krakow.pl (J.N.) \\ 2 Institute of Cardiology, Jagiellonian University Medical College, 31-202 Kraków, Poland \\ * Correspondence: mmundas@cyf-kr.edu.pl; Tel.: +48-126-143-004; Fax: +48-126-142-120 \\ + Michał Zabczyk and Joanna Natorska contributed equally.
}

check for updates

Citation: Ząbczyk, M.; Natorska, J.; Undas, A. Fibrin Clot Properties in Atherosclerotic Vascular Disease: From Pathophysiology to Clinical Outcomes. J. Clin. Med. 2021, 10, 2999. https://doi.org/10.3390/jcm10132999

Academic Editors: Anna KabłakZiembicka and Gregory Y. H. Lip

Received: 18 June 2021

Accepted: 29 June 2021

Published: 5 July 2021

Publisher's Note: MDPI stays neutral with regard to jurisdictional claims in published maps and institutional affiliations.

Copyright: (C) 2021 by the authors. Licensee MDPI, Basel, Switzerland. This article is an open access article distributed under the terms and conditions of the Creative Commons Attribution (CC BY) license (https:/ / creativecommons.org/licenses/by/ $4.0 /)$.

\begin{abstract}
Fibrin is a major component of thrombi formed on the surface of atherosclerotic plaques. Fibrin accumulation as a consequence of local blood coagulation activation takes place inside atherosclerotic lesions and contributes to their growth. The imbalance between thrombin-mediated fibrin formation and fibrin degradation might enhance atherosclerosis in relation to inflammatory states reflected by increased fibrinogen concentrations, the key determinant of fibrin characteristics. There are large interindividual differences in fibrin clot structure and function measured in plasma-based assays and in purified fibrinogen-based systems. Several observational studies have demonstrated that subjects who tend to generate denser fibrin networks displaying impaired clot lysis are at an increased risk of developing advanced atherosclerosis and arterial thromboembolic events. Moreover, the majority of cardiovascular risk factors are also associated with unfavorably altered fibrin clot properties, with their improvement following effective therapy, in particular with aspirin, statins, and anticoagulant agents. The prothrombotic fibrin clot phenotype has been reported to have a predictive value in terms of myocardial infarction, ischemic stroke, and acute limb ischemia. This review article summarizes available data on the association of fibrin clot characteristics with atherosclerotic vascular disease and its potential practical implications.
\end{abstract}

Keywords: atherosclerosis; coronary artery disease; fibrin clot; fibrinolysis; thromboembolism

\section{Introduction}

Growing evidence indicates that the formation of denser fibrin networks, which are less susceptible to lysis, characterizes patients with atherosclerosis and arterial thromboembolic events. Several cardiovascular risk factors, such as hyperlipidemia, hypertension, smoking, or diabetes have also been shown to be associated with unfavorably altered fibrin clot properties in the general population. Low-dose aspirin, statins, better diabetes control, or smoking cessation have been shown to increase fibrin clot permeability and its susceptibility to lysis. Moreover, it has been shown that non-vitamin $\mathrm{K}$ antagonist oral anticoagulants (NOACs) are able to improve fibrin clot characteristics and contribute to the reduced risk of adverse clinical outcomes. The current review article summarizes available basic research and clinical papers deposited on PubMed over the last decade regarding associations between fibrin clot phenotype and atherosclerotic vascular disease, supported by the seminal papers from previous years. Moreover, data on novel therapeutic strategies, which can potentially influence fibrin clot characteristics, have been discussed.

\section{Atherosclerotic Plaque Formation}

Atherosclerosis is a major cause of cardiovascular disease that encompasses coronary artery disease, cerebrovascular disease, peripheral arterial disease, and aortic atherosclerosis. The current concept of the pathogenesis of atherosclerosis is based on chronic inflammation associated with modified lipid deposition and dysregulated immunity within the 
arterial wall [1-3]. The key driver of atherosclerosis is elevated low-density lipoprotein (LDL) prone to undergoing oxidative modification. Following endothelial cell injury with the subsequent influx of monocytes transformed into heterogeneous macrophages and other inflammatory cells, modified LDLs are extracellularly accumulated below the endothelium, leading to fatty streaks, an initial stage of plaque formation [2]. The formation of fibroatheroma and, finally, advanced atherosclerotic plaque is associated with the secretion of multiple chemoattractants and growth factors by leukocytes and arterial smooth muscle cells (SMCs) [2]. The proliferation of SMCs is associated with the production of large amounts of extracellular connective tissue matrix, including collagen, elastin, and proteoglycans [2,3]. Oxidized LDLs (oxLDLs) are taken up by immune cells within the atherosclerotic lesion with their subsequent transformation into foam cells, leading to plaque growth [4].

Neovascularization within the advanced plaque contributes to its gradual growth in part due to intraplaque hemorrhages. An increased density of microvessels has been found in ruptured atherosclerotic plaques [5], suggesting an important link between neovascularization and plaque instability [6]. Recent studies strongly suggest that plaque healing occurs in the natural course of atherosclerosis, with higher prevalence of healed plaques in patients with chronic manifestations of atherosclerotic vascular disease compared to those with recurrent acute coronary syndromes $[7,8]$. Unstable or vulnerable atherosclerotic plaques that show such characteristics as a thin fibrous cap, high macrophage content, high amounts of proinflammatory factors or a large necrotic core composed of foam cells and extracellular cholesterol [9] are prone to rupture, accompanied by occlusive thrombosis.

\section{Blood Coagulation and Fibrin Formation in Atherosclerosis}

The role of blood coagulation in the development and progression of atherosclerotic vascular disease reaches beyond thromboembolic complications. Macrophages can produce tissue factor (TF) [4], expressed also on microvesicles and its expression is regulated by inflammatory mediators, demonstrating the link between inflammation and thrombosis [10]. TF is the high-affinity receptor and cofactor for factor (F) VII/VIIa and the resultant TF-FVIIa complex activates FIX and FX [10]. A prothrombinase complex formed on activated platelets, including FXa, its cofactor FVa converts prothrombin to thrombin, the key enzyme of blood coagulation [11]. Pro-atherogenic actions of thrombin are associated with the activation of protease-activated receptors (PARs), leading to increased endothelial permeability, SMC migration and proliferation, and the activation of platelets and leukocytes, which promote vascular calcification and plaque development [11]. Activated platelets interact with leukocytes and stimulate them to release proinflammatory cytokines, reactive oxygen species, and provide the surface for the formation of tenase and prothrombinase complexes to generate thrombin from circulating prothrombin [10]. Fibrin formation occurs when minimal amounts of prothrombin have been activated (less than $5 \%$ of thrombin generation capacity) [8]. Fibrin accumulation within atherosclerotic plaque is involved in the disease progression, especially at the late stage of plaque formation [12]. Presence of fibrin within the necrotic core of damaged plaques supports its role in plaque growth and rupture $[12,13]$. Intraplaque fibrin has been shown to be more common in symptomatic than in asymptomatic atherosclerotic plaques [12]. Thrombin-activated FXIII, which covalently crosslinks fibrin fibers, also catalyzes the formation of intermolecular bonds between $\alpha 2$-antiplasmin, fibronectin, vitronectin, thrombospondin, and collagen, which in part explains fibrin accumulation with impaired fibrinolytic degradation within the lesions. Borissoff et al. [14] showed that ApoE-/-mice, which are prone to atherosclerosis, with genetically imposed $50 \%$ reduction in prothrombin were characterized by diminished atherosclerotic lesion formation and increased plaque stability, which suggests that coagulation activation is implicated in plaque development and progression and could be a potential therapeutic target. Thrombin promotes the accumulation of neutrophils and the production of reactive oxygen species, enhancing vascular inflammation. Of pivotal importance are observations made in 2010 suggesting that enhanced blood coagulation can 
be associated with plaque stability, given the fact that TF, FII, FX, and FXII activities are diminished along with plaque transformation to advanced stage [15]. Borissoff et al. [15] have also suggested that the loss of coagulation protein activity may contribute to the risk of plaque rupture.

Adventitial fibroblasts in normal arteries are able to express TF, while in atherosclerotic lesions, TF is also expressed by SMCs, foam cells, and macrophages, which can additionally release microparticle-derived TF [16]. TF was locally detected in $43 \%$ of patients with unstable coronary syndromes and in $12 \%$ of patients with stable coronary syndromes [17]. Moreover, about $40 \%$ higher blood levels of FVII have been reported in men with vulnerable atherosclerotic plaques in the coronary arteries, compared to those who had stable plaques [18]. The colocalization of several proteins involved in blood coagulation within the plaques, largely on macrophages, microvesicles, and SMCs [19], provides the rationale for the role of a local thrombin-mediated conversion of soluble fibrinogen into fibrin, the final product of blood coagulation, in the formation of atherosclerotic lesions.

Several studies have suggested that increased fibrinogen concentration, a key determinant of fibrin formation and its characteristics, is a risk factor for atherosclerotic vascular diseases, in particular coronary artery stenosis and myocardial infarction (MI) [20-22]. In the meta-analysis of 154,211 participants from 31 prospective studies, the hazard ratio (HR) for coronary heart disease and stroke was 1.78 (95\% confidence interval [CI] 1.19-2.66) per $1 \mathrm{~g} / \mathrm{L}$ increase in plasma fibrinogen concentrations [23]. The US National Health and Nutrition Examination Survey (NHANES) study showed that fibrinogen is associated with cardiovascular disease and about a 2.5-fold higher risk of all-cause and cardiovascular mortality during the 14 years of follow-up [24]. On the other hand, a Mendelian randomization study has shown no causal effect of fibrinogen on cardiovascular disease [25].

The localization of fibrin degradation products (i.e., D-dimer) within the human arterial wall suggests their potential atherogenic properties [26]. Higher D-dimer levels can be associated with atherosclerotic plaque remodeling or ongoing fibrinolysis [27]; however, both processes may trigger lipid deposition and modulate local inflammation within atherosclerotic plaques. Moreover, high levels of plasminogen activator inhibitor type 1 (PAI-1) have been identified both in the blood of coronary artery disease (CAD) patients and within unstable plaques [28]. Some genetically determined fibrinogen disorders, dysfibrinogenemias, have also been linked to atherosclerotic vascular disease and its thromboembolic manifestations, supporting the view that alterations to fibrin structure and function might be of greater importance than the fibrinogen concentration itself [29-31].

Fibrin acts as a scaffold for intravascular blood thrombi, enhancing platelet aggregation and thrombin generation, leading to a further increase in fibrin formation [29]. Fibrin(ogen) can interact with red blood cells through specific receptors, such as CD47, and with platelets (i.e., integrin $\alpha \operatorname{Ilb} \beta 3$ or intercellular adhesion molecule 1) [29]. Cellular components embedded within the fibrin network after thrombus formation can modulate its properties. FXIII-dependent red blood cell retention in clots has been shown to impair the fibrin network structure, which delays thrombus degradation [32]. Scanning electron microscopic analysis of intracoronary thrombi obtained from patients with STsegment elevation MI (STEMI) showed that fibrin content increased from about $30 \%$ to $80 \%$, while red blood cell content decreased from $31 \%$ to $2 \%$ over time after the onset of chest pain [33,34]. It suggests that thrombus formation and its major component, fibrin, is a dynamic process $[35,36]$. Moreover, intravascular thrombi rich in red blood cells contain more neutrophils, reflecting a high thrombus burden, which has been shown to be associated with impaired reperfusion assessed at six months after the index event among patients with STEMI [35]. The presence of polyhedral erythrocytes, polyhedrocytes, has been linked with higher erythrocyte content, higher fibrinogen, and more significant stenosis in the culprit artery [36].

A contribution of blood components, in particular key coagulation factors to atherothrombosis along with potential therapeutic targets, which can modulate fibrin clot structure and function are summarized in Figure 1. 


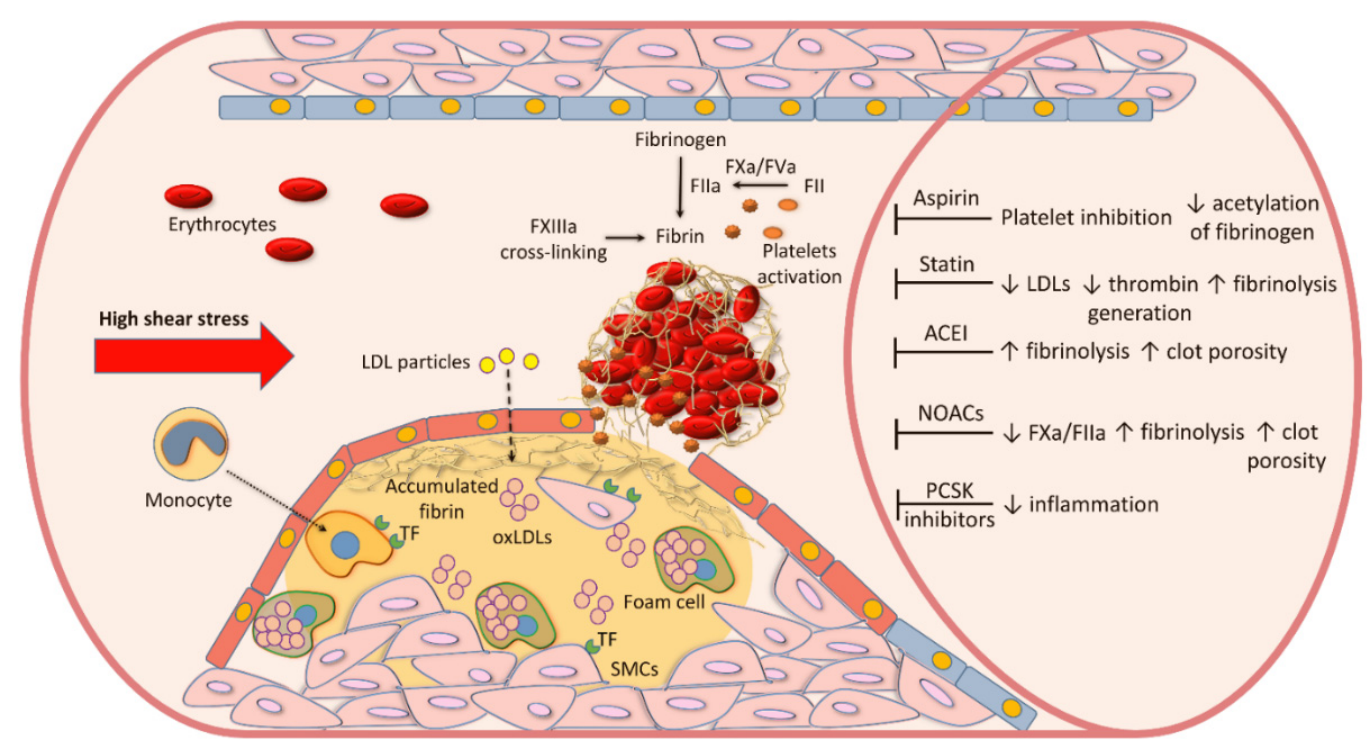

Figure 1. The initiation of an atherosclerotic lesion is associated with retention of low-density lipoproteins (LDL) and their oxidation (oxLDLs). oxLDLs stimulate recruitment of blood monocytes and their differentiation into macrophages. An uptake of oxLDLs by macrophages results in the formation of foam cells. Upon stimulation, vascular smooth muscle cells (SMCs) migrate and proliferate. Tissue factor (TF), expressed on macrophages and SMCs, is involved in coagulation activation, resulting in prothrombin (factor II, FII) conversion to thrombin (FIIa), which, in a prothrombinase complex with active FV (FVa), converts fibrinogen to fibrin. Several drugs, including aspirin, statins, angiotensinconverting enzyme inhibitors (ACEI), or non-vitamin K antagonist oral anticoagulants (NOACs) have been shown to modulate fibrin clot phenotype by different mechanisms. Proprotein convertase subtilisin kexin (PCSK) type 9 inhibitors are able to attenuate interplaque inflammation, but their effect on fibrin clot properties has not been reported yet. $\uparrow$-up-regulation, $\downarrow$-down-regulation.

\section{Measures of Fibrin Clot Properties}

Several parameters have been used in human subjects to assess fibrin clot properties. The structure of a fibrin clot generated from plasma (or purified fibrinogen) can be described using clot permeability ( $\mathrm{K}_{\mathrm{s}}$ or Darcy's constant; reflecting volume of a buffer flowing through a fibrin gel during prespecified time) [37-39], turbidity (clot absorbance measured using a spectrophotometer at 405 or $340 \mathrm{~nm}$ ) [40], or the direct measurement of fibrin fiber diameter, pore size, or fiber branching using microscopic techniques [41]. Fibrin clot susceptibility to lysis is measured by turbidimetry using several assays with either exogenous tissue plasminogen activator or plasmin added to clotted plasma [40,42,43]. A so-called prothrombotic fibrin clot phenotype encompasses reduced $\mathrm{K}_{\mathrm{s}}$ associated with typical changes in fibrin structure, such as lower fibrin fibers diameter, lower pore size area between particular fibers, and an increased number of branch points, along with faster fibrin formation and prolonged lysis time (Figure 2). 


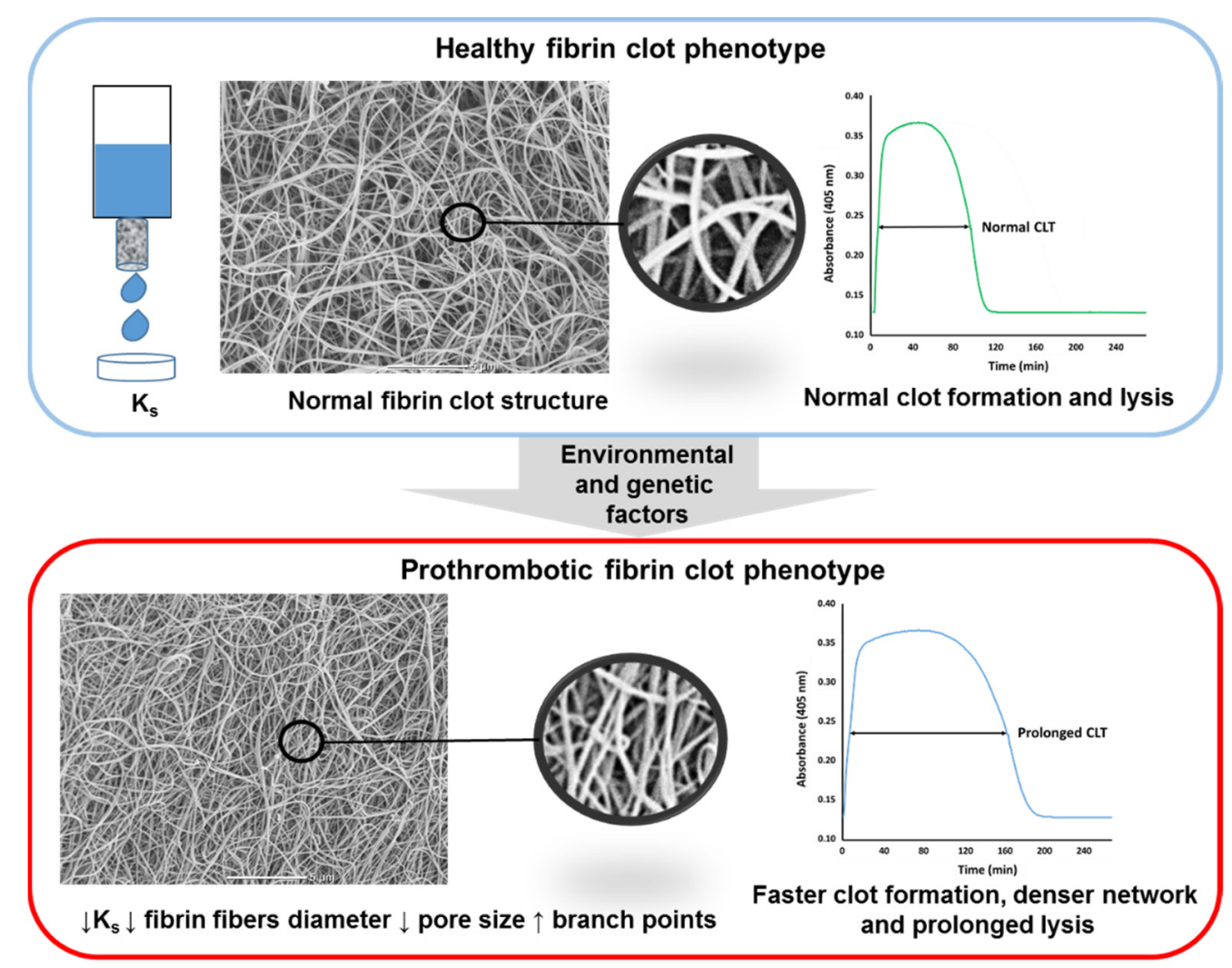

Figure 2. Fibrin clot structure differs between healthy persons and patients with atherosclerosis. A key measure describing plasma fibrin clot structure is its permeability. Reduced fibrin clot permeability $\left(\mathrm{K}_{\mathrm{s}}\right)$ is a typical feature of the prothrombotic fibrin clot phenotype, which is associated with lower fibrin fiber diameter, lower pore size area, and increased number of fibrin branch points. Faster clot formation results in denser fibrin network (indicated by higher clot turbidity), which is relatively resistant to lysis (prolonged clot lysis time; CLT). $\uparrow$-up-regulation, $\downarrow$-down-regulation.

\section{Cardiovascular Risk Factors}

The majority of well-established cardiovascular risk factors which have been reported to be associated with prothrombotic fibrin clot properties are presented in Table 1 [44-54]. Of note, there is controversy around the association of unfavorably altered clot properties and hypercholesterolemia. Low HDL cholesterol has been reported to be associated with more prothrombotic clot features [55].

Table 1. Cardiovascular risk factors in association with fibrin clot properties.

\begin{tabular}{|c|c|c|c|c|}
\hline Cardiovascular Risk Factor & Study Design & No. of Subjects & Measure & Reference \\
\hline \multirow{4}{*}{ Age } & Case-control & $\begin{array}{l}642 \text { controls (and } 421 \mathrm{MI} \\
\text { patients) }\end{array}$ & No clear effect on CLT in controls & [44] \\
\hline & Cohort study & 80 healthy controls & $\begin{array}{c}\uparrow \text { CLT and Lys50 with increasing } \\
\text { age }\end{array}$ & [45] \\
\hline & Cohort study & 2010 healthy controls & $\begin{array}{c}\uparrow \text { clot turbidity and CLT with } \\
\text { increasing age }\end{array}$ & [46] \\
\hline & Cross-sectional study & 2000 healthy controls & No clear effect on CLT & [47] \\
\hline Body-mass index (BMI) & Cohort study & 1288 healthy subjects & $\begin{array}{l}\text { BMI positively associated with } \\
\text { CLT in men and women }\end{array}$ & [48] \\
\hline
\end{tabular}


Table 1. Cont.

\begin{tabular}{|c|c|c|c|c|}
\hline Cardiovascular Risk Factor & Study Design & No. of Subjects & Measure & Reference \\
\hline $\begin{array}{l}\text { Family history of coronary } \\
\text { artery disease }\end{array}$ & Case-control & $\begin{array}{l}100 \text { healthy male relatives of } \\
\text { patients with premature } \\
\text { coronary artery disease and } 100 \\
\text { healthy controls }\end{array}$ & $\begin{array}{l}\downarrow \mathrm{K}_{\mathrm{s}} \text { and } \uparrow \text { clot turbidity in } \\
\text { relatives of patients }\end{array}$ & [39] \\
\hline \multirow{5}{*}{ Current smoking } & Case-control & $\begin{array}{c}642 \text { controls (and } 421 \mathrm{MI} \\
\text { patients) }\end{array}$ & No clear effect on CLT & [44] \\
\hline & Cross-sectional study & 2000 healthy controls & No clear effect on CLT & [47] \\
\hline & Case-control & $\begin{array}{l}34 \text { healthy male smokers and } 34 \\
\text { nonsmokers }\end{array}$ & $\begin{array}{l}\uparrow \text { clot strength, } \uparrow \text { clot turbidity, } \downarrow \\
\text { fibrin fiber diameter in smokers }\end{array}$ & [49] \\
\hline & Case-control & $\begin{array}{l}44 \text { male cigarette smokers and } 44 \\
\text { nonsmokers }\end{array}$ & $\downarrow \mathrm{K}_{\mathrm{s}}$ and $\uparrow$ clot lysis time & [50] \\
\hline & Cohort study & 30 healthy subjects & No clear effect on CLT & [51] \\
\hline Lipid profile & Cohort study & 30 healthy subjects & $\begin{array}{l}\text { Low-density lipoprotein } \\
\text { cholesterol level positively } \\
\text { associated with CLT }\end{array}$ & [51] \\
\hline \multirow[t]{3}{*}{ Diabetes } & Case-control & $\begin{array}{l}642 \text { controls (and } 421 \mathrm{MI} \\
\text { patients) }\end{array}$ & No clear effect on CLT & [44] \\
\hline & Case-control & $\begin{array}{l}150 \text { patients with type } 2 \text { diabetes } \\
\text { and } 50 \text { controls }\end{array}$ & $\begin{array}{l}\downarrow \mathrm{K}_{\mathrm{s}} \text { and } \uparrow \text { clot turbidity associated } \\
\text { with glycated hemoglobin levels }\end{array}$ & [52] \\
\hline & Interventional study & 20 type 2 diabetes subjects & $\begin{array}{c}\uparrow \mathrm{K}_{\mathrm{s}} \text { after achievement of glycemic } \\
\text { control; } \mathrm{K}_{\mathrm{s}} \text { associated with } \\
\text { glycated hemoglobin levels }\end{array}$ & [53] \\
\hline Arterial hypertension & Cohort study & $\begin{array}{l}61 \text { patients with essential arterial } \\
\text { hypertension }\end{array}$ & $\begin{array}{l}\uparrow \mathrm{K}_{\mathrm{s}}, \downarrow \text { clot lysis time, } \downarrow \text { clot } \\
\text { resistance to lysis at } 6 \text { months of } \\
\text { antihypertensive treatment }\end{array}$ & [54] \\
\hline
\end{tabular}

Myocardial infarction (MI), clot lysis time (CLT), fibrin clot permeability $\left(\mathrm{K}_{\mathrm{s}}\right), \uparrow$ —up-regulation, $\downarrow$-down-regulation.

\section{Coronary Artery Disease}

\subsection{Acute MI}

Acute MI is a leading cause of mortality in high-income countries and is a major thrombotic manifestation of atherosclerotic lesions in coronary arteries [56]. Dense fibrin networks, as evidenced by reduced $\mathrm{K}_{\mathrm{s}}$ and impaired clot susceptibility to lysis, have been reported in patients with acute MI, at least in part associated with increased oxidative stress and the extent of inflammation [57]. Prolonged clot lysis time has been confirmed as a risk factor for MI in men and women in a case-control study performed on 800 acute MI patients and 1123 controls [58]. It has been hypothesized that unfavorably modified fibrin clot properties observed in acute MI are also driven by increased thrombin generation and platelet activation, expressed by a release of large amounts of proteins affecting clot features, for instance beta-thromboglobulin and platelet factor 4 [34]. In a cohort of 421 men with acute MI compared to 642 controls, hypofibrinolysis has been associated with the risk of a first MI in young men, but not in subjects aged $\geq 50$ years, and CLT strongly correlated with body mass index [44]. As expected, patients with acute coronary events compared to stable coronary artery disease were characterized by a more prothrombotic fibrin clot phenotype, as reflected by lower $\mathrm{K}_{\mathrm{s}}$ and prolonged lysis time, related to a higher body mass index, higher blood pressure and higher C-reactive protein levels [57]. Plateletderived factors, such as P-selectin of platelet-factor 4, exert a similar effect, promoting prothrombotic fibrin clot features [59]. Serum levels of P-selectin and soluble CD40 ligand were also positively associated with thrombus fibrin content [34].

It has been demonstrated that fibrin is the main constituent (60\%) of intracoronary thrombi obtained during thrombectomy in acute STEMI (within $12 \mathrm{~h}$ since the symptom onset), with amounts increasing with time. Increased intracoronary fibrin content has also been found to be positively associated with denser plasma fibrin networks, reflected by reduced $\mathrm{K}_{\mathrm{s}}$ [36], which indicates that plasma clot characteristics have an impact on fibrin formed in intravascular thrombi. Recently, it has been suggested that intracoronary 
thrombi may have another type of fibrin on the surface. We have identified a thin layer of a fibrin biofilm on the surface of $15 \%$ intracoronary thrombi from acute MI patients, which was solely associated with higher plasma fibrinogen levels [60]. Heparin infusion during coronary angiography and thrombectomy probably reduces this proportion. This observation provided additional ex vivo evidence supporting the findings of Macrae and colleagues [61], who have shown that fibrin forms a film connected to the clot network and covers whole blood clots, which may protect against infiltration by bacteria or viruses, with potential impact on wound healing and thrombus fragmentation. Despite that there are no available reports describing the presence of fibrin biofilm on thrombi obtained from other locations. The relevance of the biofilm formation in human thrombosis requires further investigation.

It is unclear whether fibrin clot composition differs among patients with the same condition. Proteomics data has shown that clot-bound protein composition can influence fibrin properties [62]. A preliminary shotgun proteomic analysis performed on plasma clots from four patients during acute MI and two months later revealed time-dependent changes in the clot structure, which may influence clot stability and its susceptibility for lysis [63]. Differences in fibrinolysis proteins, such as increased amounts of $\alpha 2$-antiplasmin, in acute MI may at least in part explain time-dependent changes in the clot structure following MI [63].

From a practical point of view, the issue of prognostication based on plasma fibrin clot characteristics appears to be of vital importance. Growing evidence indicates that the prothrombotic fibrin phenotype can predict cardiovascular events. A PLATO substudy performed on 4354 patients following acute MI has shown that a validated turbidimetric assay employed to assess plasma clot lysis time and clot maximum turbidity at hospital discharge, while on dual antiplatelet therapy, is able to predict adverse clinical outcomes during a 12 month follow-up period [64]. After adjustment for cardiovascular risk factors, each $50 \%$ increase in lysis time was associated with a 1.17-times higher risk of cardiovascular death or MI, and a 1.36-fold higher risk of cardiovascular death alone. A similar increase in plasma clot maximum turbidity was associated with a 1.24-fold increased risk of death (hazard ratio 1.24, 95\% confidence interval 1.03-1.50) [64]. Fibrin clot density and resistance to lysis increased with higher levels of $\mathrm{N}$-terminal pro B-type natriuretic peptide (NT-proBNP) and troponin T, which are known to be associated with a greater inflammatory response. The authors concluded that higher NT-proBNP levels can be associated with worse outcomes as a consequence of impaired fibrin clot features, which may lead to an increased risk of atherothrombosis [64]. Even after additional adjustment for leukocyte count, high-sensitivity C-reactive protein, high-sensitivity troponin T, cystatin C, NT-proBNP, and growth differentiation factor- 15 levels, the association with death remained significant solely for lysis time [64]. It remains to be established whether clot density, or permeability, could have a similar prognostic value.

\subsection{Stable $C A D$}

Stable CAD, defined as angina pectoris, MI history, or presence of atherosclerotic plaques, has been associated with unfavorably modified fibrin clot properties [65]. Reduced fibrin clot lysability has been reported in asymptomatic women with present coronary plaque determined by computed tomography angiography, compared to both women without plaque and men, suggesting a sex-dependent link between coronary atherosclerosis and prolonged clot lysis time [66]. Patients with symptomatic CAD formed clots with more rigid structures and increased fibrin fiber mass-to-length ratio [67]. A history of MI in 33 young patients with documented CAD was associated with prothrombotic fibrin clot characteristics, including increased clot stiffness and a slower fibrinolysis rate, compared to healthy controls [68]. Increased lipoprotein(a) levels, a well-established risk factor for premature atherosclerosis, have been shown to alter fibrin clot properties and were associated with reduced $\mathrm{K}_{\mathrm{s}}$ and prolonged clot lysis time in patients with a history of MI [69]. Moreover, in advanced CAD patients, lipoprotein(a), a genetically determined risk factor 
for premature atherosclerosis, levels predicted $\mathrm{K}_{\mathrm{s}}$ but not lysis time [70]. Similarly, type 2 diabetes concomitant to $\mathrm{CAD}$ was associated with prolonged clot lysis time and a more compact fibrin clot structure compared to non-diabetic CAD patients [71]. The rs495828 risk allele within the $\mathrm{ABO}$ locus, which is known to be associated with an increased risk of MI in CAD patients, has also been shown to be associated with a more compact fibrin network structure, as evidenced by higher clot maximum absorbance, but not lysis time, among 773 stable CAD patients [72]. In a long-term follow-up study, the area under the curve of turbidimetrically monitored clot formation and lysis predicted future cardiovascular events in stable CAD ( $\mathrm{HR}=2.4,95 \% \mathrm{CI} 1.2-4.6)$ [73]. Altogether, CAD is associated with the prothrombotic clot phenotype governed by several largely environmental factors.

\section{Peripheral Arterial Disease}

Prothrombotic fibrin clot properties were observed for the first time in 2009 in patients with intermittent claudication, a typical manifestation of peripheral arterial disease (PAD) $[74,75]$ which occurs in $18-20 \%$ in individuals over 70 years of age, including the most serious presentation, limb ischemia, affecting up to $3 \%$ of patients with PAD. [76]. The group from Leeds reported that unfavorably altered fibrin clot structure and function are detectable in apparently healthy close relatives of patients with claudication [74,75]. In 106 PAD patients, there was a reduction by $20 \%$ in $\mathrm{K}_{\mathrm{s}}$ when compared to controls, and it was associated with $31 \%$ prolonged CLT; the two alterations in fibrin properties predicted PAD progression during long-term follow-up [77]. Similarly, $13.4 \%$ reduced $\mathrm{K}_{\mathrm{s}}$ with no difference in CLT was found in patients with a history of acute lower limb ischemia compared to individuals without any history of such event [77]. Interestingly, premature PAD has also been identified as the clinical condition associated with a less favorable fibrin clot phenotype, in particular 30\% lower clot permeability, compared to normal conditions, and no difference in the phenotype is observed in typical older PAD patients [78]. Moreover, in critical limb ischemia patients, who represent up to 3\% of patients with PAD, restenosis detected within one year following endovascular therapy was associated with slightly reduced $\mathrm{K}_{\mathrm{s}}$ and prolonged CLT at baseline, accompanied by elevated thrombin generation and von Willebrand factor antigen; however, the fibrin clot variables cannot predict re-intervention, amputation, and death during further 3-year follow-up [79].

\section{Aortic Aneurysm}

Scott et al. [80] have shown that patients with abdominal aortic aneurysm (AAA) form denser fibrin clots with smaller pore sizes which are more resistant to lysis. Such prothrombotic clot phenotype was associated with the size of aneurysm and may play a role in its development. A further study performed on 169 AAA patients, including about $40 \%$ with a history of stable angina or MI, showed that plasma levels of D-dimer and thrombinantithrombin (TAT) complexes were independent predictors of AAA growth rate [81]. An increase in D-dimer level by $500 \mathrm{ng} / \mathrm{mL}$, or TAT level by $1 \mu \mathrm{g} / \mathrm{mL}$ was associated with enlargement of the aneurysm size by 0.21 and $0.24 \mathrm{~mm}$ per year, respectively. However, it is not known to date whether prothrombotic fibrin clot phenotype in patients with aneurysm may contribute to clinical outcomes in particular its rupture or rapid enlargement.

\section{Pharmacological Treatment and Fibrin Clot Properties}

\subsection{Cholesterol-Lowering Agents}

Statins (3-hydroxy-methylglutaryl coenzyme A reductase inhibitors) may exert several cholesterol-independent antithrombotic effects, including the down-regulation of TF expression and enhanced protein $C$ activation via increased endothelial thrombomodulin expression [82]. Although data linking hypercholesterolemia with prothrombotic clot characteristics are limited and unconvincing, statins (simvastatin or atorvastatin at a dose of $40 \mathrm{mg}$ /day for 4 weeks) used in patients with stable CAD to effectively reduce LDL cholesterol have been shown to reduce plasma clot density, reflected by higher $\mathrm{K}_{\mathrm{s}}$ and shortened 
CLT, despite no impact on plasma fibrinogen levels [83]. Favorable effects of statins on fibrin clot structure and function were supported by the study in which a 3-month use of simvastatin $(40 \mathrm{mg} / \mathrm{d})$ led to a slight, though significant, increase in $\mathrm{K}_{\mathrm{s}}$ and a shortened clot lysis time in patients with LDL cholesterol $<3.4 \mathrm{mmol} / \mathrm{L}$ free of clinically evident CAD, like in the JUPITER trial with rosuvastatin [84]. This effect appeared to be associated with a decrease in CRP concentrations, suggesting links between the antithrombotic and anti-inflammatory effects of statins.

Novel therapeutic strategies to lower LDL cholesterol based on fully humanized monoclonal antibodies that bind free plasma proprotein convertase subtilisin/kexin type 9 (PCSK9) [85], different cholesteryl ester transfer protein (CETP) inhibitors [86], and antisense oligonucleotides targeting apolipoprotein(a) $[87,88]$ are currently under investigation. To our knowledge, their potential effects on fibrin clot properties have not been investigated yet.

\subsection{Aspirin}

Aspirin was the first effective antiplatelet therapy for the prevention of ischemic events in patients with atherosclerotic vascular disease. Aspirin treatment has been shown to be associated with the formation of thicker fibrin fibers and improved clot susceptibility to lysis in stable CAD patients [89]. The mechanism of aspirin action on fibrin clot structure is unclear; however, fibrinogen acetylation $[90,91]$ has been postulated as a major contributor despite controversies as to whether aspirin at therapeutic doses (75-150 mg/day) might exert such effects observed largely in vitro. Interestingly, low-dose aspirin $(75 \mathrm{mg} /$ day) has been shown to exert a stronger effect on fibrin clot properties than $320 \mathrm{mg} /$ day $[92,93]$. In ten stable CAD patients treated with aspirin at a dose of $75 \mathrm{mg} /$ day, aspirin withdrawal was associated with $32 \%$ reduced $\mathrm{K}_{\mathrm{s}}$ after one week and $41 \%$ reduced $\mathrm{K}_{\mathrm{s}}$ after two weeks when compared to values observed during treatment [94]. It is unclear to what extent fibrin-related mechanisms might add to the well-known antithrombotic effect caused by cyclooxygenase- 1 inhibition and antiaggregatory effects on platelets.

\subsection{Angiotensin-Converting Enzyme Inhibitors (ACEI)}

Antihypertensive therapy with ACEI has been found to modulate fibrin clot properties in association with reduced complement component C3 levels [54]; however, similar effects were noted for other agents lowering blood pressure. In a double-blind study performed in men aged $<70$ years with a history of MI or hospitalization for unstable angina, a four-week treatment with quinapril was associated with a $\mathrm{K}_{\mathrm{s}}$ increase by $13 \%$ and shortening of clot lysis time by $28 \%$ [83]. It has been suggested that the effect of ACEIs on increased fibrin clot porosity can be associated with reduced plasma fibrinogen levels [95].

\subsection{NOACs}

NOACs, including rivaroxaban and apixaban, which are selective and direct FXa inhibitors, and dabigatran as a direct thrombin inhibitor, are used to prevent and treat thromboembolic events [96]. Clots formed from normal plasma spiked with rivaroxaban $(174 \mathrm{ng} / \mathrm{mL})$ or apixaban $(128 \mathrm{ng} / \mathrm{mL})$ at therapeutic levels resulted in a less dense and more permeable clot structure with thicker fibers [97]. Varin et al. [98] have demonstrated more permeable fibrin networks composed of thicker fibrin fibers in plasma spiked with rivaroxaban at a concentration of $0.15 \mu \mathrm{g} / \mathrm{mL}$, which was in line with the findings of JanionSadowska et al. [99] made in plasma-based assays in patients 2-6 $\mathrm{h}$ after rivaroxaban intake (20 mg/day). A seminal COMPASS trial has shown that rivaroxaban use at a dose of $2.5 \mathrm{mg}$ twice daily combined with $100 \mathrm{mg}$ of aspirin can prevent cardiovascular death in patients with advanced cardiovascular disease, mostly represented by those with stable CAD $[100,101]$. It has also been shown that pharmacological inhibition of FXa promotes the regression of advanced atherosclerotic plaques and enhances plaque stability in mice treated with rivaroxaban $(1.2 \mathrm{mg} / \mathrm{g})$ for 14 weeks [102], suggesting that the inhibition of FXa may be beneficial both in the prevention and regression of atherosclerotic vascular 
disease by down-regulated activation of PARs. The influence of low-dose rivaroxaban on fibrin clot phenotype still remains to be elucidated; however, based on the current knowledge, it can be assumed that rivaroxaban $2.5 \mathrm{mg}$ bid might improve fibrin properties like rivaroxaban $20 \mathrm{mg} /$ day, though to a smaller extent, and thus contributing to reduced risk of adverse clinical outcomes largely thromboembolic by nature.

\section{Clinical Implications}

The formation of dense fibrin networks which are relatively resistant to lysis has been observed in patients with atherosclerotic vascular disease, in particular CAD and PAD, along with those who experience arterial thromboembolism. The prothrombotic features of fibrin clots that are largely determined by environmental factors can be improved by the control of cardiovascular risk factors, in particular the normalization of glycemia and statin use. Growing evidence suggests that measures of clot characteristics, such as clot permeability and clot lysis time, may predict arterial thromboembolic events. Therefore, fibrin clot measures could serve as prognostic markers in patients at risk of arterial thromboembolism. However, there is a need for large studies to validate the available observations and standardization of the assays used to characterize the clot phenotype, though the first step initiated by the scientific subcommittee of the International Society on Thrombosis and Haemostasis has been made to implement the measurement of $K_{s}$ and CLT in clinical practice $[43,103]$.

\section{Conclusions}

Taken together, several studies demonstrated that the formation of more compact fibrin networks displaying lower susceptibility to lysis are implicated in the progression of atherosclerosis and the occurrence of thromboembolic manifestations, in particular MI (see Table 2). The observations might support accumulating data on clinical benefits from the use of anticoagulant agents in the prevention of cardiovascular mortality. It remains to be established whether any specific modulators of fibrinolytic efficiency might be useful in the prevention of clinical outcomes in atherosclerotic vascular disease, still the major cause of morbidity and mortality worldwide.

Table 2. Table summarizing the recent data on plasma fibrin clot properties, including fibrin clot permeability $\left(\mathrm{K}_{\mathrm{s}}\right)$ and clot lysis time (CLT) in atherosclerotic patients.

\begin{tabular}{|c|c|c|c|}
\hline Author (Year of Publication) & Study Type & Sample Size, Condition & Main Findings \\
\hline Sadowski et al. (2014) [34] & Cohort study & 40 acute MI patients & $\begin{array}{l}\text { Plasma levels of platelet activation } \\
\text { markers correlated with thrombus } \\
\text { fibrin content }\end{array}$ \\
\hline Zalewski et al. (2015) [36] & Cohort study & 80 acute MI patients & $\begin{array}{l}\text { Low } \mathrm{K}_{\mathrm{s}} \text { was independently } \\
\text { associated with high fibrin content } \\
\text { within the intracoronary thrombi }\end{array}$ \\
\hline Sumaya W et al. (2018) [64] & Cohort study & $\begin{array}{l}4354 \text { acute coronary syndrome } \\
\text { patients }\end{array}$ & $\begin{array}{l}\text { Prolonged lysis time was associated } \\
\text { with cardiovascular death/MI }\end{array}$ \\
\hline $\begin{array}{l}\text { Ramanathan R et al. } \\
\text { (2018) [66] }\end{array}$ & Cross-sectional study & $\begin{array}{l}138 \text { individuals without } \\
\text { known cardiovascular disease }\end{array}$ & $\begin{array}{l}\text { Women with coronary plaques had } \\
\text { reduced fibrin clot lysability } \\
\text { compared to women or men } \\
\text { without coronary plaques }\end{array}$ \\
\hline $\begin{array}{l}\text { Neergaard-Petersen S et al. } \\
\text { (2014) [71] }\end{array}$ & Cohort study & $\begin{array}{l}581 \text { CAD patients, including } \\
148 \text { subjects with type } \\
2 \text { diabetes }\end{array}$ & $\begin{array}{l}\text { Type } 2 \text { diabetes in CAD patients } \\
\text { was associated with prothrombotic } \\
\text { fibrin clot compared to non-diabetic } \\
\text { CAD patients }\end{array}$ \\
\hline
\end{tabular}


Table 2. Cont.

\begin{tabular}{|c|c|c|c|}
\hline Author (Year of Publication) & Study Type & Sample Size, Condition & Main Findings \\
\hline $\begin{array}{l}\text { Winther-Larsen A et al. } \\
\text { (2020) [72] }\end{array}$ & Cohort study & 773 patients with stable CAD & $\begin{array}{c}\text { The } A B O \text { risk allele (rs495828) was } \\
\text { associated with a more compact } \\
\text { fibrin network in stable CAD } \\
\text { patients }\end{array}$ \\
\hline $\begin{array}{l}\text { Neergaard-Petersen S et al. } \\
\text { (2020) [73] }\end{array}$ & Cohort study & 786 patients with stable CAD & $\begin{array}{c}\text { Increased area under the curve of } \\
\text { clot formation and lysis predicted } \\
\text { cardiovascular events }\end{array}$ \\
\hline Karpińska I et al. (2020) [77] & Case-control study & $\begin{array}{l}43 \text { patients with a history of } \\
\text { acute limb ischemia, } 43 \\
\text { patients with cryptogenic } \\
\text { stroke, } 43 \text { controls }\end{array}$ & $\begin{array}{c}\text { Increased clot density and } \\
\text { hypofibrinolysis characterized } \\
\text { patients with acute limb ischemia } \\
\text { compared to controls }\end{array}$ \\
\hline Nowakowski et al. (2019) [79] & Case-control study & $\begin{array}{l}85 \text { patients with critical limb } \\
\text { ischemia and restenosis and } \\
47 \text { PAD patients }\end{array}$ & $\begin{array}{c}\text { Restenosis compared to PAD was } \\
\text { associated with reduced } \mathrm{K}_{\mathrm{s}} \text { and } \\
\text { prolonged CLT }\end{array}$ \\
\hline Scott DJ et al. (2011) [80] & Case-control study & $\begin{array}{l}42 \text { patients with large AAA, } \\
40 \text { patients with small AAA, } \\
\text { and } 49 \text { controls }\end{array}$ & $\begin{array}{l}\text { Patients with AAA compared to } \\
\text { controls formed denser plasma } \\
\text { clots, which were more resistant } \\
\text { to lysis }\end{array}$ \\
\hline
\end{tabular}

Myocardial infarction (MI), coronary artery disease (CAD), peripheral arterial disease (PAD), abdominal aortic aneurysm (AAA).

Author Contributions: Conceptualization, A.U.; methodology, M.Z. and J.N.; writing-original draft preparation, M.Z. and A.U.; writing—review and editing, A.U.; visualization, M.Z. and J.N.; supervision, A.U.; project administration, A.U.; funding acquisition, A.U. All authors have read and agreed to the published version of the manuscript.

Funding: This research was funded by the Jagiellonian University Medical College, grant number N41/DBS/000184.

Conflicts of Interest: The authors declare no conflict of interest.

\section{References}

1. Libby, P.; Ridker, P.M.; Hansson, G.K. Progress and challenges in translating the biology of atherosclerosis. Nature 2011, 473, 317-325. [CrossRef]

2. Schaftenaar, F.; Frodermann, V.; Kuiper, J.; Lutgens, E. Atherosclerosis: The interplay between lipids and immune cells. Curr. Opin. Lipidol. 2016, 27, 209-215. [CrossRef] [PubMed]

3. Barrett, T.J. Macrophages in atherosclerosis regression. Arterioscler. Thromb. Vasc. Biol. 2020, 40, 20-33. [CrossRef] [PubMed]

4. Jaipersad, A.S.; Lip, G.Y.; Silverman, S.; Shantsila, E. The role of monocytes in angiogenesis and atherosclerosis. J. Am. Coll. Cardiol. 2014, 63, 1-11. [CrossRef]

5. Moreno, P.R.; Purushothaman, K.R.; Fuster, V.; Echeverri, D.; Truszczynska, H.; Sharma, S.K.; Badimon, J.J.; O'Connor, W.N. Plaque neovascularization is increased in ruptured atherosclerotic lesions of human aorta: Implications for plaque vulnerability. Circulation 2004, 110, 2032-2038. [CrossRef]

6. Vergallo, R.; Porto, I.; D’Amario, D.; Annibali, G.; Galli, M.; Benenati, S.; Bendandi, F.; Migliaro, S.; Fracassi, F.; Aurigemma, C.; et al. Coronary atherosclerotic phenotype and plaque healing in patients with recurrent acute coronary syndromes compared with patients with long-term clinical stability: An in vivo optical coherence tomography study. JAMA Cardiol. 2019, 4, 321-329. [CrossRef] [PubMed]

7. Fracassi, F.; Crea, F.; Sugiyama, T.; Yamamoto, E.; Uemura, S.; Vergallo, R.; Porto, I.; Lee, H.; Fujimoto, J.; Fuster, V.; et al. Healed culprit plaques in patients with acute coronary syndromes. J. Am. Coll. Cardiol. 2019, 73, 2253-2263. [CrossRef]

8. Mann, K.G.; Brummel, K.; Butenas, S. What is all that thrombin for? J. Thromb. Haemost. 2003, 1, 1504-1514. [CrossRef]

9. Brown, R.A.; Shantsila, E.; Varma, C.; Lip, G.Y. Current understanding of atherogenesis. Am. J. Med. 2017, 130, 268-282. [CrossRef] [PubMed]

10. Grover, S.P.; Mackman, N. Tissue factor: An essential mediator of hemostasis and trigger of thrombosis. Arterioscler. Thromb. Vasc. Biol. 2018, 38, 709-725. [CrossRef] [PubMed]

11. Borissoff, J.I.; Spronk, H.M.; Heeneman, S.; ten Cate, H. Is thrombin a key player in the 'coagulation-atherogenesis' maze? Cardiovasc. Res. 2009, 82, 392-403. [CrossRef] [PubMed] 
12. Borissoff, J.I.; Spronk, H.M.; ten Cate, H. The hemostatic system as a modulator of atherosclerosis. N. Engl. J. Med. 2011, 364, 1746-1760. [CrossRef] [PubMed]

13. Finn, A.V.; Nakano, M.; Narula, J.; Kolodgie, F.D.; Virmani, R. Concept of vulnerable/unstable plaque. Arterioscler. Thromb. Vasc. Biol. 2010, 30, 1282-1292. [CrossRef]

14. Borissoff, J.I.; Otten, J.J.T.; Heeneman, S.; Leenders, P.; van Oerle, R.; Soehnlein, O.; Loubele, S.T.B.G.; Hamulyák, K.; Hackeng, T.M.; Daemen, M.J.A.P.; et al. Genetic and pharmacological modifications of thrombin formation in apolipoprotein e-deficient mice determine atherosclerosis severity and atherothrombosis onset in a neutrophil-dependent manner. PLoS ONE. 2013, 8, e55784. [CrossRef]

15. Borissoff, J.I.; Heeneman, S.; Kilinç, E.; Kassák, P.; Van Oerle, R.; Winckers, K.; Govers-Riemslag, J.W.; Hamulyák, K.; Hackeng, T.M.; Daemen, M.J.; et al. Early atherosclerosis exhibits an enhanced procoagulant state. Circulation 2010, 122, 821-830. [CrossRef]

16. Grover, S.P.; Mackman, N. Tissue factor in atherosclerosis and atherothrombosis. Atherosclerosis 2020, 307, 80-86. [CrossRef]

17. Annex, B.H.; Denning, S.M.; Channon, K.M.; Sketch, M.H., Jr.; Stack, R.S.; Morrissey, J.H.; Peters, K.G. Differential expression of tissue factor protein in directional atherectomy specimens from patients with stable and unstable coronary syndromes. Circulation 1995, 91, 619-622. [CrossRef]

18. Ragino, Y.I.; Striukova, E.V.; Murashov, I.S.; Polonskaya, Y.V.; Volkov, A.M.; Kurguzov, A.V.; Chernjavskii, A.M.; Kashtanova, E.V. Association of some hemostasis and endothelial dysfunction factors with probability of presence of vulnerable atherosclerotic plaques in patients with coronary atherosclerosis. BMC Res. Notes 2019, 12, 336. [CrossRef] [PubMed]

19. Tavora, F.; Cresswell, N.; Li, L.; Ripple, M.; Burke, A. Immunolocalisation of fibrin in coronary atherosclerosis: Implications for necrotic core development. Pathology 2010, 42, 15-22. [CrossRef] [PubMed]

20. Dunn, E.J.; Ariëns, R.A.; de Lange, M.; Snieder, H.; Turney, J.H.; Spector, T.D.; Grant, P.J. Genetics of fibrin clot structure: A twin study. Blood 2004, 103, 1735-1740. [CrossRef]

21. Gao, X.Y.; Zhou, B.Y.; Zhang, M.Z.; Zhao, X.; Qing, P.; Zhu, C.G.; Wu, N.Q.; Guo, Y.L.; Gao, Y.; Li, X.L.; et al. Association between fibrinogen level and the severity of coronary stenosis in 418 male patients with myocardial infarction younger than 35 years old. Oncotarget 2017, 8, 81361-81368. [CrossRef]

22. Tatli, E.; Ozcelik, F.; Aktoz, M. Plasma fibrinogen level may predict critical coronary artery stenosis in young adults with myocardial infarction. Cardiol. J. 2009, 16, 317-320.

23. Fibrinogen Studies Collaboration; Danesh, J.; Lewington, S.; Thompson, S.G.; Lowe, G.D.; Collins, R.; Kostis, J.B.; Wilson, A.C.; Folsom, A.R.; Wu, K.; et al. Plasma fibrinogen level and the risk of major cardiovascular diseases and nonvascular mortality: An individual participant meta-analysis. JAMA 2005, 294, 1799-1809.

24. Pieters, M.; Ferreira, M.; de Maat, M.P.M.; Ricci, C. Biomarker association with cardiovascular disease and mortality-The role of fibrinogen. A report from the NHANES study. Thromb. Res. 2021, 198, 182-189. [CrossRef] [PubMed]

25. Ward-Caviness, C.K.; de Vries, P.S.; Wiggins, K.L.; Huffman, J.E.; Yanek, L.R.; Bielak, L.F.; Giulianini, F.; Guo, X.; Kleber, M.E.; Kacprowski, T.; et al. Mendelian randomization evaluation of causal effects of fibrinogen on incident coronary heart disease. PLoS ONE 2019, 14, e0216222. [CrossRef]

26. Smith, E.B.; Keen, G.A.; Grant, A.; Stirk, C. Fate of fibrinogen in human arterial intima. Arteriosclerosis 1990, 10, $263-275$. [CrossRef] [PubMed]

27. Kleinegris, M.C.; ten Cate, H.; ten Cate-Hoek, A.J. D-dimer as a marker for cardiovascular and arterial thrombotic events in patients with peripheral arterial disease. A systematic review. Thromb. Haemost. 2013, 110, 233-243. [PubMed]

28. Kohler, H.P.; Grant, P.J. Mechanisms of disease: Plasminogen-activator inhibitor type 1 and coronary artery disease. N. Engl. J. Med. 2000, 342, 1792-1801.

29. Undas, A.; Casini, A. Congenital structural and functional fibrinogen disorders: A primer for internists. Pol. Arch. Intern. Med. 2019, 129, 913-920. [CrossRef] [PubMed]

30. Kryczka, K.E.; Płoski, R.; Księżycka, E.; Kruk, M.; Kostrzewa, G.; Kowalik, I.; Demkow, M.; Lubiszewska, B. The association between the insertion/deletion polymorphism of the angiotensin-converting enzyme gene and the plasma fibrinogen level in women and men with premature coronary artery atherosclerosis. Pol. Arch. Intern. Med. 2020, 130, 748-756. [CrossRef]

31. Treliński, J.; Witkowski, M.; Chojnowski, K.; Neerman-Arbez, M.; Wypasek, E.; Undas, A. Fibrinogen Łódź: A new cause of dysfibrinogenemia associated with recurrent thromboembolic arterial events. Pol. Arch. Intern. Med. 2019, 129, 934-935. [CrossRef]

32. Byrnes, J.R.; Duval, C.; Wang, Y.; Hansen, C.E.; Ahn, B.; Mooberry, M.J.; Clark, M.A.; Johnsen, J.M.; Lord, S.T.; Lam, W.A.; et al. Factor XIIIa-dependent retention of red blood cells in clots is mediated by fibrin $\alpha$-chain crosslinking. Blood 2015, 126, 1940-1948. [CrossRef]

33. Cines, D.B.; Lebedeva, T.; Nagaswami, C.; Hayes, V.; Massefski, W.; Litvinov, R.I.; Rauova, L.; Lowery, T.J.; Weisel, J.W. Clot contraction: Compression of erythrocytes into tightly packed polyhedra and redistribution of platelets and fibrin. Blood 2014, 123, 1596-1603. [CrossRef] [PubMed]

34. Sadowski, M.; Zabczyk, M.; Undas, A. Coronary thrombus composition: Links with inflammation, platelet and endothelial markers. Atherosclerosis 2014, 237, 555-561. [CrossRef]

35. Yunoki, K.; Naruko, T.; Sugioka, K.; Inaba, M.; Iwasa, Y.; Komatsu, R.; Itoh, A.; Haze, K.; Inoue, T.; Yoshiyama, M.; et al. Erythrocyte-rich thrombus aspirated from patients with ST-elevation myocardial infarction: Association with oxidative stress and its impact on myocardial reperfusion. Eur. Heart. J. 2012, 33, 1480-1490. [CrossRef] [PubMed] 
36. Zalewski, J.; Bogaert, J.; Sadowski, M.; Woznicka, O.; Doulaptsis, K.; Ntoumpanaki, M.; Ząbczyk, M.; Nessler, J.; Undas, A. Plasma fibrin clot phenotype independently affects intracoronary thrombus ultrastructure in patients with acute myocardial infarction. Thromb. Haemost. 2015, 113, 1258-1269.

37. Carr, M.E.; Shen, L.L.; Hermans, J. Mass-length ratio of fibrin fibers from gel permeation and light scattering. Biopolymers 1977, 16, 1-15. [CrossRef] [PubMed]

38. Blombäck, B.; Okada, M. Fibrin gel structure and clotting time. Thromb. Res. 1982, 25, 51-70. [CrossRef]

39. Mills, J.D.; Ariëns, R.A.; Mansfield, M.W.; Grant, P.J. Altered fibrin clot structure in the healthy relatives of patients with premature coronary artery disease. Circulation 2002, 106, 1938-1942. [CrossRef] [PubMed]

40. Carter, A.M.; Cymbalista, C.M.; Spector, T.D.; Grant, P.J.; EuroCLOT Investigators. Heritability of clot formation, morphology, and lysis: The EuroCLOT study. Arterioscler. Thromb. Vasc. Biol. 2007, 27, 2783-2789. [CrossRef]

41. Collet, J.P.; Park, D.; Lesty, C.; Soria, J.; Soria, C.; Montalescot, G.; Weisel, J.W. Influence of fibrin network conformation and fibrin fiber diameter on fibrinolysis speed: Dynamic and structural approaches by confocal microscopy. Arterioscler. Thromb. Vasc. Biol. 2000, 20, 1354-1361. [CrossRef] [PubMed]

42. Smith, A.A.; Jacobson, L.J.; Miller, B.I.; Hathaway, W.E.; Manco-Johnson, M.J. A new euglobulin clot lysis assay for global fibrinolysis. Thromb. Res. 2003, 112, 329-337. [CrossRef] [PubMed]

43. Pieters, M.; Philippou, H.; Undas, A.; de Lange, Z.; Rijken, D.C.; Mutch, N.J.; Subcommittee on Factor XIII and Fibrinogen, and the Subcommittee on Fibrinolysis. An international study on the feasibility of a standardized combined plasma clot turbidity and lysis assay: Communication from the SSC of the ISTH. J. Thromb. Haemost. 2018, 16, 1007-1012. [CrossRef] [PubMed]

44. Meltzer, M.E.; Doggen, C.J.; de Groot, P.G.; Rosendaal, F.R.; Lisman, T. Reduced plasma fibrinolytic capacity as a potential risk factor for a first myocardial infarction in young men. Br. J. Haematol. 2009, 145, 121-127. [CrossRef] [PubMed]

45. Siudut, J.; Iwaniec, T.; Plens, K.; Pieters, M.; Undas, A. Determinants of plasma fibrin clot lysis measured using three different assays in healthy subjects. Thromb. Res. 2021, 197, 1-7. [CrossRef]

46. Swanepoel, A.C.; De Lange, Z.; Cockeran, M.; Pieters, M. Lifestyle influences changes in fibrin clot properties over a 10-year period on a population level. Thromb. Haemost. 2021. [CrossRef]

47. de Lange, Z.; Pieters, M.; Jerling, J.C.; Kruger, A.; Rijken, D.C. Plasma clot lysis time and its association with cardiovascular risk factors in black Africans. PLoS ONE 2012, 7, e48881. [CrossRef] [PubMed]

48. Eksteen, P.; Pieters, M.; de Lange, Z.; Kruger, H.S. The association of clot lysis time with total obesity is partly independent from the association of PAI-1 with central obesity in African adults. Thromb. Res. 2015, 136, 415-421. [CrossRef]

49. Barua, R.S.; Sy, F.; Srikanth, S.; Huang, G.; Javed, U.; Buhari, C.; Margosan, D.; Ambrose, J.A. Effects of cigarette smoke exposure on clot dynamics and fibrin structure: An ex vivo investigation. Arterioscler. Thromb. Vasc. Biol. 2010, 30, 75-79. [CrossRef] [PubMed]

50. Undas, A.; Topór-Madry, R.; Tracz, W.; Pasowicz, M. Effect of cigarette smoking on plasma fibrin clot permeability and susceptibility to lysis. Thromb. Haemost. 2009, 102, 1289-1291.

51. Pieters, M.; Guthold, M.; Nunes, C.M.; de Lange, Z. Interpretation and validation of maximum absorbance data obtained from turbidimetry analysis of plasma clots. Thromb. Haemost. 2020, 120, 44-54. [CrossRef] [PubMed]

52. Dunn, E.J.; Ariëns, R.A.; Grant, P.J. The influence of type 2 diabetes on fibrin structure and function. Diabetologia 2005, 48, 1198-1206. [CrossRef] [PubMed]

53. Pieters, M.; Covic, N.; van der Westhuizen, F.H.; Nagaswami, C.; Baras, Y.; Toit Loots, D.; Jerling, J.C.; Elgar, D.; Edmondson, K.S.; van Zyl, D.G.; et al. Glycaemic control improves fibrin network characteristics in type 2 diabetes-A purified fibrinogen model. Thromb. Haemost. 2008, 99, 691-700.

54. Rajzer, M.; Wojciechowska, W.; Kawecka-Jaszcz, K.; Undas, A. Plasma fibrin clot properties in arterial hypertension and their modification by antihypertensive medication. Thromb. Res. 2012, 130, 99-103. [CrossRef]

55. Zabczyk, M.; Hońdo, Ł.; Krzek, M.; Undas, A. High-density cholesterol and apolipoprotein AI as modifiers of plasma fibrin clot properties in apparently healthy individuals. Blood Coagul. Fibrinolysis 2013, 24, 50-54. [CrossRef] [PubMed]

56. Herrington, W.; Lacey, B.; Sherliker, P.; Armitage, J.; Lewington, S. Epidemiology of Atherosclerosis and the potential to reduce the global burden of atherothrombotic disease. Circ. Res. 2016, 118, 535-546. [CrossRef]

57. Undas, A.; Szułdrzynski, K.; Stepien, E.; Zalewski, J.; Godlewski, J.; Tracz, W.; Pasowicz, M.; Zmudka, K. Reduced clot permeability and susceptibility to lysis in patients with acute coronary syndrome: Effects of inflammation and oxidative stress. Atherosclerosis 2008, 196, 551-557. [CrossRef]

58. Leander, K.; Blombäck, M.; Wallén, H.; He, S. Impaired fibrinolytic capacity and increased fibrin formation associate with myocardial infarction. Thromb. Haemost. 2012, 107, 1092-1099. [CrossRef] [PubMed]

59. Gajos, G.; Siniarski, A.; Natorska, J.; Ząbczyk, M.; Siudut, J.; Malinowski, K.P.; Gołębiowska-Wiatrak, R.; Rostoff, P.; Undas, A. Polyhedrocytes in blood clots of type 2 diabetic patients with high cardiovascular risk: Association with glycemia, oxidative stress and platelet activation. Cardiovasc. Diabetol. 2018, 17, 146. [CrossRef]

60. Zabczyk, M.; Natorska, J.; Zalewski, J.; Undas, A. Fibrin biofilm can be detected on intracoronary thrombi aspirated from patients with acute myocardial infarction. Cardiovasc. Res. 2019, 115, 1026-1028. [CrossRef]

61. Macrae, F.L.; Duval, C.; Papareddy, P.; Baker, S.R.; Yuldasheva, N.; Kearney, K.J.; McPherson, H.R.; Asquith, N.; Konings, J.; Casini, A.; et al. A fibrin biofilm covers blood clots and protects from microbial invasion. J. Clin. Investig. 2018, 128, 3356-3368. [CrossRef] 
62. Zabczyk, M.; Stachowicz, A.; Natorska, J.; Olszanecki, R.; Wiśniewski, J.R.; Undas, A. Plasma fibrin clot proteomics in healthy subjects: Relation to clot permeability and lysis time. J. Proteom. 2019, 208, 103487. [CrossRef]

63. Suski, M.; Siudut, J.; Zabczyk, M.; Korbut, R.; Olszanecki, R.; Undas, A. Shotgun analysis of plasma fibrin clot-bound proteins in patients with acute myocardial infarction. Thromb. Res. 2015, 135, 754-759. [CrossRef]

64. Sumaya, W.; Wallentin, L.; James, S.K.; Siegbahn, A.; Gabrysch, K.; Bertilsson, M.; Himmelmann, A.; Ajjan, R.A.; Storey, R.F. Fibrin clot properties independently predict adverse clinical outcome following acute coronary syndrome: A PLATO substudy. Eur. Heart J. 2018, 39, 1078-1085. [CrossRef] [PubMed]

65. Undas, A. Fibrin clot properties and their modulation in thrombotic disorders. Thromb. Haemost. 2014, 112, 32-42. [CrossRef] [PubMed]

66. Ramanathan, R.; Gram, J.B.; Sidelmann, J.J.; Dey, D.; Kusk, M.W.; Nørgaard, B.L.; Sand, N.P.R. Sex difference in fibrin clot lysability: Association with coronary plaque composition. Thromb. Res. 2019, 174, 129-136. [CrossRef] [PubMed]

67. Greilich, P.E.; Carr, M.E.; Zekert, S.L.; Dent, R.M. Quantitative assessment of platelet function and clot structure in patients with severe coronary artery disease. Am. J. Med. Sci. 1994, 307, 15-20. [CrossRef] [PubMed]

68. Collet, J.P.; Allali, Y.; Lesty, C.; Tanguy, M.L.; Silvain, J.; Ankri, A.; Blanchet, B.; Dumaine, R.; Gianetti, J.; Payot, L.; et al. Altered fibrin architecture is associated with hypofibrinolysis and premature coronary atherothrombosis. Arterioscler. Thromb. Vasc. Biol. 2006, 26, 2567-2573. [CrossRef]

69. Undas, A.; Stepien, E.; Tracz, W.; Szczeklik, A. Lipoprotein(a) as a modifier of fibrin clot permeability and susceptibility to lysis. J. Thromb. Haemost. 2006, 4, 973-975. [CrossRef]

70. Undas, A.; Plicner, D.; Stepień, E.; Drwiła, R.; Sadowski, J. Altered fibrin clot structure in patients with advanced coronary artery disease: A role of C-reactive protein, lipoprotein(a) and homocysteine. J. Thromb. Haemost. 2007, 5, 1988-1990. [CrossRef]

71. Neergaard-Petersen, S.; Hvas, A.M.; Kristensen, S.D.; Grove, E.L.; Larsen, S.B.; Phoenix, F.; Kurdee, Z.; Grant, P.J.; Ajjan, R.A. The influence of type 2 diabetes on fibrin clot properties in patients with coronary artery disease. Thromb. Haemost. 2014, 112, 1142-1150. [CrossRef]

72. Winther-Larsen, A.; Christiansen, M.K.; Larsen, S.B.; Nyegaard, M.; Neergaard-Petersen, S.; Ajjan, R.A.; Würtz, M.; Grove, E.L.; Jensen, H.K.; Kristensen, S.D.; et al. The ABO locus is associated with increased fibrin network formation in patients with stable coronary artery disease. Thromb. Haemost. 2020, 120, 1248-1256. [CrossRef] [PubMed]

73. Neergaard-Petersen, S.; Larsen, S.B.; Grove, E.L.; Kristensen, S.D.; Ajjan, R.A.; Hvas, A.M. Imbalance between fibrin clot formation and fibrinolysis predicts cardiovascular events in patients with stable coronary artery disease. Thromb. Haemost. 2020, 120, 75-82. [CrossRef]

74. Bhasin, N.; Parry, D.J.; Scott, D.J.; Ariëns, R.A.; Grant, P.J.; West, R.M. Regarding “Altered fibrin clot structure and function in individuals with intermittent claudication". J. Vasc. Surg. 2009, 49, 1088-1089. [CrossRef] [PubMed]

75. Bhasin, N.; Ariëns, R.A.; West, R.M.; Parry, D.J.; Grant, P.J.; Scott, D.J. Altered fibrin clot structure and function in the healthy first-degree relatives of subjects with intermittent claudication. J. Vasc. Surg. 2008, 48, 1497-1503. [CrossRef]

76. Olinic, D.M.; Stanek, A.; Tătaru, D.A.; Homorodean, C.; Olinic, M. Acute limb ischemia: An update on diagnosis and management. J. Clin. Med. 2019, 8, 1215. [CrossRef]

77. Karpińska, I.A.; Nowakowski, T.; Wypasek, E.; Plens, K.; Undas, A. A prothrombotic state and denser clot formation in patients following acute limb ischemia of unknown cause. Thromb. Res. 2020, 187, 32-38. [CrossRef] [PubMed]

78. Okraska-Bylica, A.; Wilkosz, T.; Słowik, L.; Bazanek, M.; Konieczyńska, M.; Undas, A. Altered fibrin clot properties in patients with premature peripheral artery disease. Pol. Arch. Med. Wewn. 2012, 122, 608-615. [CrossRef]

79. Nowakowski, T.; Malinowski, K.P.; Niżankowski, R.; Iwaniec, T.; Undas, A. Restenosis is associated with prothrombotic plasma fibrin clot characteristics in endovascularly treated patients with critical limb ischemia. J. Thromb. Thrombolysis 2019, 47, 540-549. [CrossRef]

80. Scott, D.J.; Prasad, P.; Philippou, H.; Rashid, S.T.; Sohrabi, S.; Whalley, D.; Kordowicz, A.; Tang, Q.; West, R.M.; Johnson, A.; et al. Clot architecture is altered in abdominal aortic aneurysms and correlates with aneurysm size. Arterioscler. Thromb. Vasc. Biol. 2011, 31, 3004-3010. [CrossRef] [PubMed]

81. Sundermann, A.C.; Saum, K.; Conrad, K.A.; Russell, H.M.; Edwards, T.L.; Mani, K.; Björck, M.; Wanhainen, A.; Owens, A.P. Prognostic value of D-dimer and markers of coagulation for stratification of abdominal aortic aneurysm growth. Blood Adv. 2018, 2, 3088-3096. [CrossRef] [PubMed]

82. Undas, A.; Brummel-Ziedins, K.E.; Mann, K.G. Anticoagulant effects of statins and their clinical implications. Thromb. Haemost. 2014, 111, 392-400.

83. Undas, A.; Celinska-Löwenhoff, M.; Löwenhoff, T.; Szczeklik, A. Statins, fenofibrate, and quinapril increase clot permeability and enhance fibrinolysis in patients with coronary artery disease. J. Thromb. Haemost. 2006, 4, 1029-1036. [CrossRef] [PubMed]

84. Undas, A.; Topór-Madry, R.; Tracz, W. Simvastatin increases clot permeability and susceptibility to lysis in patients with LDL cholesterol below $3.4 \mathrm{mmol} /$. Pol. Arch. Med. Wewn. 2009, 119, 354-359. [CrossRef] [PubMed]

85. Stein, E.A.; Mellis, S.; Yancopoulos, G.D.; Stahl, N.; Logan, D.; Smith, W.B.; Lisbon, E.; Gutierrez, M.; Webb, C.; Wu, R.; et al. Effect of a monoclonal antibody to PCSK9 on LDL cholesterol. N. Engl. J. Med. 2012, 366, 1108-1118. [CrossRef] [PubMed]

86. Hovingh, G.K.; Kastelein, J.J.; van Deventer, S.J.; Round, P.; Ford, J.; Saleheen, D.; Rader, D.J.; Brewer, H.B.; Barter, P.J. Cholesterol ester transfer protein inhibition by TA-8995 in patients with mild dyslipidaemia (TULIP): A randomised, double-blind, placebocontrolled phase 2 trial. Lancet 2015, 386, 452-460. [CrossRef] 
87. Tsimikas, S.; Viney, N.J.; Hughes, S.G.; Singleton, W.; Graham, M.J.; Baker, B.F.; Burkey, J.L.; Yang, Q.; Marcovina, S.M.; Geary, R.S.; et al. Antisense therapy targeting apolipoprotein(a): A randomised, double-blind, placebo-controlled phase 1 study. Lancet 2015, 386, 1472-1483. [CrossRef]

88. Viney, N.J.; van Capelleveen, J.C.; Geary, R.S.; Xia, S.; Tami, J.A.; Yu, R.Z.; Marcovina, S.M.; Hughes, S.G.; Graham, M.J.; Crooke, R.M.; et al. Antisense oligonucleotides targeting apolipoprotein(a) in people with raised lipoprotein(a): Two randomised, double-blind, placebo-controlled, dose-ranging trials. Lancet 2016, 388, 2239-2253. [CrossRef]

89. Williams, S.; Fatah, K.; Ivert, T.; Blombäck, M. The effect of acetyl salicylic acid on fibrin gel lysis by tissue plasminogen activator. Blood Coagul. Fibrinolysis 1995, 6, 718-725. [CrossRef]

90. Ajjan, R.A.; Standeven, K.F.; Khanbhai, M.; Phoenix, F.; Gersh, K.C.; Weisel, J.W.; Kearney, M.T.; Ariëns, R.A.; Grant, P.J. Effects of aspirin on clot structure and fibrinolysis using a novel in vitro cellular system. Arterioscler. Thromb. Vasc. Biol. 2009, 29, 712-717. [CrossRef]

91. Svensson, J.; Bergman, A.C.; Adamson, U.; Blombäck, M.; Wallén, H.; Jörneskog, G. Acetylation and glycation of fibrinogen in vitro occur at specific lysine residues in a concentration dependent manner: A mass spectrometric and isotope labeling study. Biochem. Biophys. Res. Commun. 2012, 421, 335-342. [CrossRef]

92. Williams, S.; Fatah, K.; Hjemdahl, P.; Blombäck, M. Better increase in fibrin gel porosity by low dose than intermediate dose acetylsalicylic acid. Eur. Heart. J. 1998, 19, 1666-1672. [CrossRef]

93. He, S.; Bark, N.; Wang, H.; Svensson, J.; Blombäck, M. Effects of acetylsalicylic acid on increase of fibrin network porosity and the consequent upregulation of fibrinolysis. J. Cardiovasc. Pharmacol. 2009, 53, 24-29. [CrossRef] [PubMed]

94. Fatah, K.; Beving, H.; Albåge, A.; Ivert, T.; Blombäck, M. Acetylsalicylic acid may protect the patient by increasing fibrin gel porosity. Is withdrawing of treatment harmful to the patient? Eur. Heart J. 1996, 17, 1362-1366. [CrossRef]

95. Scott, E.M.; Ariëns, R.A.S.; Grant, P.J. Genetic and environmental determinants of fibrin structure and function. Relevance to clinical disease. Arterioscler. Thromb. Vasc. Biol. 2004, 24, 1558-1566. [CrossRef]

96. Franchini, M.; Mannucci, P.M. Direct oral anticoagulants and venous thromboembolism. Eur. Respir. Rev. 2016, 25, 295-302. [CrossRef]

97. Gauer, J.S.; Riva, N.; Page, E.M.; Philippou, H.; Makris, M.; Gatt, A.; Ariëns, R.A.S. Effect of anticoagulants on fibrin clot structure: A comparison between vitamin K antagonists and factor Xa inhibitors. Res. Pract. Thromb. Haemost. 2020, 4, 1269-1281. [CrossRef] [PubMed]

98. Varin, R.; Mirshahi, S.; Mirshahi, P.; Klein, C.; Jamshedov, J.; Chidiac, J.; Perzborn, E.; Mirshahi, M.; Soria, C.; Soria, J. Whole blood clots are more resistant to lysis than plasma clots-Greater efficacy of rivaroxaban. Thromb. Res. 2013, 131, e100-e109. [CrossRef] [PubMed]

99. Janion-Sadowska, A.; Natorska, J.; Siudut, J.; Zabczyk, M.; Stanisz, A.; Undas, A. Plasma fibrin clot properties in the G20210A prothrombin mutation carriers following venous thromboembolism: The effect of rivaroxaban. Thromb. Haemost. 2017, 117, 1739-1749. [CrossRef]

100. Connolly, S.J.; Eikelboom, J.W.; Bosch, J.; Dagenais, G.; Dyal, L.; Lanas, F.; Metsarinne, K.; O’Donnell, M.; Dans, A.L.; Ha, J.W.; et al. Rivaroxaban with or without aspirin in patients with stable coronary artery disease: An international, randomised, double-blind, placebo-controlled trial. Lancet 2018, 391, 205-218. [CrossRef]

101. Desperak, P.; Hudzik, B.; Gasior, M. Assessment of patients with coronary artery disease who may benefit from the use of rivaroxaban in the real world: Implementation of the COMPASS trial criteria in the TERCET registry population. Pol. Arch. Intern. Med. 2019, 129, 460-468. [CrossRef] [PubMed]

102. Posthuma, J.J.; Posma, J.J.N.; van Oerle, R.; Leenders, P.; van Gorp, R.H.; Jaminon, A.M.G.; Mackman, N.; Heitmeier, S.; Schurgers, L.J.; Ten Cate, H.; et al. Targeting Coagulation factor Xa promotes regression of advanced atherosclerosis in apolipoprotein-E deficient mice. Sci. Rep. 2019, 9, 3909. [CrossRef] [PubMed]

103. Pieters, M.; Undas, A.; Marchi, R.; De Maat, M.P.; Weisel, J.; Ariëns, R.A.; Factor XIII and Fibrinogen Subcommittee of the Scientific and Standardisation Committee of the International Society for Thrombosis and Haemostasis. An international study on the standardization of fibrin clot permeability measurement: Methodological considerations and implications for healthy control values. J. Thromb. Haemost. 2012, 10, 2179-2181. [CrossRef] [PubMed] 